\title{
11. Pension systems as risk management: a case of the Baltic states
}

\section{Olga Rajevska}

\section{INTRODUCTION}

A pension system is a set of methods aimed at managing the risk of subsistence shortage in old age. Different elements of the pension system are focused on managing specific dimensions of this risk: the risk of low interest rates in funded schemes, risk of devaluation of savings, risk of longevity, risk of poor health, risk of a drop in living standards, and so on. Some of the risks are personal, while others are public or corporate, such as the risk of financial unsustainability or insolvency.

The aim of this chapter is to explore how risk perception and understanding have evolved by means of analysis and synthesis of experience in the functioning of pension systems under the circumstances of high uncertainty. It poses several questions: How do the existing pension schemes in the Baltic states reflect the way these risks are managed? What elements of pension systems are responsible for the implementation of these tasks? What similarities and differences can be found among Latvia, Estonia and Lithuania in the approaches to risk management?

The research is based on an analysis of the development of pension legislation in the three countries (laws and cabinet regulations), political documents (for example, reports of the World Bank; Organisation for Economic Co-operation and Development, or OECD; and European Commission, and documents from the International Labour Organization, or ILO) and statistical data (from the Eurostat online database, national social insurance agencies and financial supervisory authorities), demonstrating the performance of the considered pension systems. The author has also used numerous publications of pension system researchers from the Baltic states and their colleagues from other European countries.

The applicable risk management strategies are classified into four major groups: risk avoidance, risk reduction (mitigation), risk sharing (and risk transfer), and risk retention (acceptance) (see, for example, Dorfman and Cather 
2013). We will consider what strategies and combinations of strategies can be found in the pension systems of the three Baltic states.

The study is organised as follows. First, a brief overview of the development of modern multi-pillar pension systems in Estonia, Latvia and Lithuania after restoration of their independence in the early 1990s, followed by an examination of the institutional design of the pension pillars, while at the same time looking at the risks that these pillars are supposed to manage. The development of financing principles of the Baltic pension systems and retirement age reforms are considered. There is a separate section for each of the three pillars, starting with a general description of its operational structure followed by a more detailed analysis of changes in recent years. In analysing pension pillars, their design and performance are assessed in terms of the effectiveness of managing the risks associated with pension provision. The risks specific to each pillar are reviewed, as well as the mechanisms aimed at controlling these particular risks. The chapter ends with conclusions, summarising trends in pension system development in the three Baltic states in recent years and assessing the set of risk management strategies used in them.

\section{DEVELOPMENT OF MODERN PENSION SYSTEMS IN THE BALTIC STATES}

Estonia, Latvia and Lithuania entered their new eras of independence with identical security systems for the elderly, inherited from the Soviet period. Pensions in the USSR were financed from the general state budget and no individual contributions by workers were made; entitlement to a pension was based on previous work experience and the amount of benefit linked to the size of wages during the last years of employment. Work record books were kept for all employees.

The processes of radical economic and political reforms in the early 1990s brought about the reform of the old social security system. All three countries promptly split financing of the pensions from the general budget by introducing social insurance budgets replenished by contributions made by employees and employers (or, in the case of Estonia, only by employers). While Lithuania did not reform the Soviet pension formula comprehensively until 1995, Estonia and Latvia adopted new pension laws in 1991, modifying into more generous pensions and keeping the amount of pension linked to preceding wages (Leppik and Võrk 2006; Vanovska 2006).

However, the new Estonian and Latvian laws had very short lives, having collided with the economic reality of collapsing enterprises, a sharp decrease in contribution bases and hyperinflation. In 1993, both Estonia and Latvia removed the earnings-related component from the formula, and pension benefit started to consist of two parts: a flat-rate basic pension and a com- 
ponent dependent on the length of service (that is, each year of employment and equalised periods amounted to a certain monetary value). Although the earnings-related component formally did exist in Lithuania, it took a very small fraction of the benefit, complemented with flat-rate supplements.

Thus, by the mid 1990s there was a strong demand for reformed pension systems capable of balancing assets and liabilities, and at the same time providing incentives for the population to pay contributions by linking the amount of pension to individual earnings for the whole working period. Lithuania was the first Baltic country to introduce contribution-based pensions, in 1995.

Pension reforms in the Baltic countries were very much influenced by the World Bank's seminal report 'Averting the Old-Age Crisis: Policies to Protect the Old and Promote Growth' (1994), which introduced the concept of the three-pillar pension system and actively propagated the substantial shift to privatisation of mandatory pensions. Redistribution in benefit formulas, widely regarded as excessive during the Soviet period, has been reduced or eliminated (Fultz and Hirose 2019).

So, by the middle of the 2000 s, the structure of pension systems in all three countries included:

- Pillar I: state-managed compulsory pension schemes, operating on pay-as-you-go (PAYG) principles, financed by social insurance contributions ('pension tax') and offering earnings-related benefits;

- Pillar II: privately managed, compulsory and fully funded pension schemes, financed by social insurance contributions and participants' contributions;

- Pillar III: privately managed voluntary pension schemes, in the form of pension funds or life insurance policies offered by insurance companies.

\section{PILLAR I: SOCIAL INSURANCE PUBLIC PAYG SCHEMES}

International social security standards lay down certain general principles with regard to the organisation and management of social security systems. Thus, the ILO Social Security (Minimum Standards) Convention, 1952 (No. 102), ${ }^{1}$ maintains that the state must accept general responsibility for the due provision of benefits and proper administration of the institutions involved, and that social security systems should be financed collectively by means of insurance contributions or taxation or both, so that the risks are spread among the members of the community. An essential part of the social security concept is pooling the risk through collective assumption of the financial burden of paying benefits (ILO 2017).

First pillars in the Baltic states are based on PAYG social insurance principles. 
The Latvian first-pillar benefit is earned by all insured individuals by registering part of their social insurance contributions in personalised Notional Pension Capital accounts. No actual money transfer takes place - this capital exists only as a record in the State Social Insurance Agency database - and the whole scheme is known as NDC: notional (or, in another reading of the abbreviation, 'non-financial') defined contribution. The pension value is the accrued notional capital at retirement divided by the projected life expectancy at retirement age. The accrued notional capital is annually valorised (up-rated) in line with the increase in the covered wage bill (that is, the total sum of all socially insured wages in the country).

The first-pillar benefit in Estonia and Lithuania is comprised of two main components: a general basic non-contributory one (in Estonia it is absolutely flat, but in Lithuania it depends on the length of service), and an individual insurance component, constructed quite similarly in the two countries and based on variations of a pension point system (pension point is the ratio of a person's social insurance contributions and the nationwide average social contributions in a particular year).

In 2019, the system of financing the mandatory pillars in Lithuania was radically changed. A fundamental reform was implemented: almost the whole social insurance contribution was transferred to the employee's side, and only the individual pension component based on pension points was funded from social contributions, while the basic pension funding was transferred to the general budget. This reform implied an essential change in the nominal wage, rate of social insurance contribution and personal income tax. Despite all these changes, the level of financing of the Pillar I pension system remained the same (only indexed by the obligatory index prescribed by law).

Another important novelty was the introduction of a pension supplement financed from the general state budget for those whose pension benefit (general + individual) is lower than the minimum subsistence level (in 2020: $€ 257$ per month). With this supplement, pensions are automatically raised to the minimum, reducing the risk of poverty.

Both the basic component and monetary value of one pension point are regularly revised (indexed). Pensions that are being paid are annually indexed, taking into account the increases in the covered wage bill and consumer price index (the latter in Estonia and Latvia only).

\section{Risks of PAYG Schemes}

From the state's point of view as the pension provider, the main systemic risk in Pillar I is considered to be financial unsustainability of the social insurance system and a pension budget deficit. Separating the social budget from the general budget helped the payment of pensions to be covered by collecting 
social insurance contributions from current employees. Automatic balancing mechanisms linking pension indexation and notional capital valorisation to the changes in the collected contributions (rather than changes in prices or average wages) have served this purpose in all three countries.

A rapid decline in population (mainly due to emigration) made it necessary for all Baltic States to take urgent measures to prevent social budget deficits. In order to increase the revenues, either the contribution rate or the number of contributors (or both) had to be increased. There was almost no direct increase in social contributions rate, but during the crisis years of 2008-2012 the share of pension contributions directed to Pillar II private funds was temporarily reduced in order to increase the revenues of the PAYG pillar. With the return to economic growth, the position of private funds has strengthened again, but in Latvia and Lithuania the pre-crisis proportions were not fully restored.

When the second pillars were established, Latvia and Lithuania financed them by carving out a share of social insurance contributions from the PAYG pillar, while Estonia introduced an additional contribution - 2 per cent of gross insured wage - to finance it (on top of carving out 4 percentage points, or p.p., from the social tax). This additional contribution was not formally considered an increase in the social tax though. Lithuania changed the financing scheme of the second pillar in a similar manner in 2014 by levying an additional 2 per cent on the gross wage of Pillar II participants, not changing the overall rate of social insurance contributions. Thus, in 2018 in Latvia 100 per cent of the second-pillar receipts were PAYG pension scheme transfers; in Lithuania, 80 per cent came from public sources (the PAYG pension scheme and state budget transfers) and 20 per cent came from private contributions from the participants (Lazutka, Poviliunas and Zalimiene 2018); while in Estonia two-thirds came from the collected social tax (PAYG scheme) and one-third from private contributions of the participants. ${ }^{2}$ As a result of the aforementioned reform in 2019 in Lithuania, Pillar II is no longer financed from social contributions in that country.

To increase pension budget revenues, and reduce pension expenditures at the same time, another mechanism was used much more actively than the change in the social contribution rate. The number of contributors was increased by raising the statutory retirement age.

The author's calculations based on Eurostat data show that if Latvia had kept the retirement age at the 'Soviet' level, 55 years for women/60 years for men, there would be a 7 per cent increase in old-age pensioners in 2018 compared to 1990, with a simultaneous decrease of 33 per cent in the number of people of working age. Due to the increase of the statutory retirement age, which has been in place for more than 20 years, the number of both groups decreased proportionally, by 21 per cent by the end of 2018. Thus, it was possible to retain the old-age dependency ratio at the constant level. 
The pioneer in raising the retirement age was Estonia, where it started in 1994. The initial regulation prescribed raising the statutory age by five years for both men and women (to reach 65 and 60 years of age respectively) in 10 years, increasing it by six months each year. In 1996, it was decided that the pace of growth was rising very fast, and was not fair to people born in different months of the same year, so it was reduced to four months per year (on average), and the finish line was shifted to 2007. In 1998, a whole package of laws on pension reform was adopted, changing the entire system. These included the equalisation of the age for men and women: the new goal was set at 63 years for both genders. Men reached this milestone in 2001, and for women the gradual increase lasted until 2016. At the same time, the possibility of early retirement with a reduced pension was introduced (Leppik and Võrk 2006).

Lithuania has been raising the retirement age since 1995. As in Estonia, it was planned to maintain the difference between men and women, but to make it smaller: to raise the age by 2.5 years for men and five years for women by 2009 , increasing each year by two months for men and four months for women. In this country, in contrast to Estonia, the pace of growth was not slowed, but accelerated in 2001 to six months in a year, so the first stage of the statutory age increase was completed by 2003 for men and 2006 for women (Lazutka 2006).

Latvia has been raising the retirement age since 1996. Initially it was planned that only women's statutory age would be raised to 60 years, the same level as men. The rise was very fast; in the first year it was raised immediately by one year, and then by six months per year. In 1999, after the Russian default crisis, ${ }^{3}$ the pension budget was threatened by a deficit, and it was decided to raise the retirement age by another two years in order to make it 62 years for both men and women. The government was planning to do it in one go, right from the following year, but opposition parties organised a referendum and the terms were relaxed, and the increase was kept to six months in a year. The raise was completed by 2003 for men and by 2008 for women.

There were talks about the need to further raise the retirement age in the early 2000s, but they did not receive sufficient support before the crisis. The shocks of 2008-2011, with falling employment, intensified emigration, sharp depletion of social budgets and austerity measures, all contributed to the adoption of the second wave of raising the retirement age in all three countries in 2010-2012.

Estonians were first to legislate the new increase: in 2010, despite criticism from the opposition and trade unions, a law was adopted, stating that from the point the female statutory age equalled the male one (63 years) in 2016, a further increase of three months a year would commence, to be completed by 2026, and reaching 65 years of age (Võrk, Leppik and Segaert 2010). 
Similarly, at the beginning of 2010, a draft law was prepared in Lithuania to gradually raise the statutory retirement age to 65 years, starting in 2012 at a pace of six months per year. In the final version of the law adopted in 2011, the rate of growth slowed down to two months per year for men and four months per year for women, as in the 1990s. The goal is 65 years in 2026. At the same time, the rules on early retirement were relaxed (Jankauskiene and Medaiskis 2011, 2012).

In Latvia, the government first proposed raising the retirement age by six months a year, starting in 2016 and reaching the goal of 65 years by 2021. But in 2012 it was decided to halve the speed (as in Estonia), but to start two years earlier, in 2014, and extend the increase to 2025.

Thus, in 2020, the statutory retirement age in Estonia and Latvia is 63.75 years for both men and women, and in Lithuania 64 years for men and 63 years for women. Currently, the retirement age continues to rise in all three countries.

In December 2018, Estonia adopted the law with a new statutory pension age formula that will tie the statutory retirement age to life expectancy from 2027. That is, by 2026 it will reach 65 years of age, and then it will become 65 years plus an increase in life expectancy in comparison with the reference interval (2018-2022). ${ }^{4}$ Also, from 2021, Estonia has introduced the so-called flexible pension instead of early/deferred retirement. The flexible pension will be actuarially neutral (the present system of deferred pensions is unfavourable for pension budgets) and should motivate people to prolong their working lives.

However, all these measures have not been able to fully protect pension budgets from deficit, and interventions from general tax budgets were necessary. ESSPROS (Eurostat) data show that old-age pensions ${ }^{5}$ in the Baltic states are to a greater extent financed from social contributions compared to European Union (EU) countries. The average EU proportion in 2015 was as follows: 65 per cent of funding came from social contributions, 20 per cent from general taxation and 15 per cent from other revenues (interest on investments and other sources). The respective proportions in the Baltic States were: Estonia -72.9 per cent +23.2 per cent +3.9 per cent, Latvia -77.5 per cent + 17 per cent +5.4 per cent, and Lithuania -83.5 per cent +16.1 per cent + less than 0.4 per cent (Spasova and Ward 2019). In Estonia and Lithuania deficits in the social insurance (PAYG) pension budget were covered by general tax revenue, while in the case of Latvia, formally the social insurance budget was not in deficit, but financing of the so-called pension supplements (a flat-rate allowance for pre-reform years of employment) was transferred from social insurance to general tax revenue. Similarly, since 2016 the state budget subsidises service pensions as well even after they are converted to old-age pensions when the pensioner reaches the official retirement age. There is a clear logical 
rationale in such a transfer of financing, since the rights to these benefits were not earned through social contributions.

Given the current demographic situation and the extremely low level of adequacy of old-age pensions, it seems inevitable that the general budget will increasingly participate in the financing of public pension insurance.

From the point of view of the risks borne by scheme contributors and not by the provider, PAYG schemes should safeguard them against the risk of poverty and ensuing social exclusion, the risk of declining living standards and the risk of devaluation of pension benefits with time.

Existing mechanisms do not sufficiently insure participants against these risks: statutory minimum pensions are well below the risk-of-poverty thresholds (particularly in Latvia), replacement rates are lower than the average EU indicators and are projected to decrease further (European Commission 2018), and indexation rules do not fully ensure that the purchasing power is maintained over time. This is the cause of a considerably higher level of poverty among old women than old men in the Baltics: in 2018, in the age group 65-plus, 53.3 per cent of women in Estonia were at risk of poverty or social exclusion as opposed to 36.1 per cent of men (the risk, therefore is 1.48 times higher for women), in Latvia 53.4 per cent of women and 40.1 per cent of men (risk ratio: 1.33) and in Lithuania 49.2 per cent of women and 29.8 per cent of men (risk ratio: 1.65). The EU-28 averages in 2017 equalled 20.6 per cent of women and 15.2 per cent of men (that is, 1.35 times higher for women). The basic pensions were not generous enough to keep women above the poverty risk, while men had additional income sources that reduced this risk. It should be noted that female pensioners tend to be older than men due to greater longevity, and they tend to be single (Ebbinghaus 2019).

The redistributive role of pensions is weaker in the Baltics than in the EU on average. The author has compared Gini coefficients before and after pensions; the calculations based on Eurostat dataset ilc_di12c and ilc_di12b were carried out in the same way as in the work of Dunajevas and Skučiene (2016), updated for the last available indicators of 2018. While including pensions (but not other social transfers) in disposable income causes a drop of 15.2 p.p. (that is, by 29.7 per cent) in the Gini coefficient in the EU-28, in Estonia the Gini coefficient drops by 10 p.p. (22.7 per cent), in Latvia by 9.9 p.p. (20.6 per cent) and in Lithuania by 10.5 p.p. (20.5 per cent). However, it can be argued whether the Gini coefficient is the best measure to assess the redistributive effect in the system.

As of 2021, the Estonian pension system will become more solidarity-based: if at present the number of points earned in a calendar year depends only on the amount of contributions made (the national average brings in one point, twice the national average brings in two points, and so on), then from 2021 the length of service will be taken into account along with the contributions paid. 
Thus, an employee with half the average contributions, who has worked for a full year, will receive not 0.5 points as presently, but 0.75 (50 per cent $\times 1$ year +50 per cent $\times 0.5$ of the average contributions). The employee with the insured income which is twice as high as the average and with a full year of service will receive 1.5 points $(50$ per cent $\times 1$ year +50 per cent $\times 2)$ instead of the current two points. An employee with an insured monthly income that is twice the average, but who has worked only six months, will receive 0.75 points instead of the current one point.

Risks associated with labour market turbulences, such as unemployment, the spread of precarious employment contracts, and bogus and true self-employment, have been largely the responsibility of workers themselves in the DC systems adopted in the Baltic states. Latvia, lacking a non-contributory element in its pension formula, has gone further than others in transferring risks to individuals. The author's calculations show that the drop in total length of insured employment from 40 years to 20 years brought an average-earner in Latvia a drop in replacement rate by 38 p.p. (from 62 per cent to 24 per cent) and in Lithuania by 27 p.p. (from 52 per cent to 25 per cent), while in Estonia the drop was only 15 p.p. (from 48 per cent to 33 per cent). For lower-earners the differences were even greater, although for higher-wage-earners shorter employment records affected their replacement rates to a lesser extent (Rajevska and Voroncuka 2019).

The share of inadequately low old-age pension benefits is quite significant in the Baltic countries: in 2018, the at-risk-of-poverty rates in the age group 65-plus reached 37.7 per cent in Lithuania, 45.7 per cent in Latvia and 46.3 per cent in Estonia (compared to the EU-28 average rate of 15.9 per cent), and the aggregate pension replacement rate was $c .40$ per cent in the three study countries (EU-28: 58 per cent). Not surprisingly, many pensioners continue working after reaching the statutory age, and employment rates in the age group 65-plus are high: 9.2 per cent in Lithuania, 9.4 per cent in Latvia and 13.4 per cent in Estonia, as opposed to 6.1 per cent in EU-28 (Eurostat). Willingness to remain in employment is higher in Latvia and Estonia than anywhere in the EU. The answer 'as late as possible' to the question 'Until what age do you want to work?' was given by about 40 per cent of respondents, which is more than twice as high as the EU-28 average (slightly below 20 per cent). Meanwhile, Lithuanians gave this answer in about 25 per cent of cases (Eurofound 2017).

Risk management strategies we consider in the PAYG pillar are mainly classified as risk sharing (among current pensioners, among current contributors and recipients) and risk transfer (for example, between PAYG and a funded pillar, also by attracting financing from general budgets). The state is mitigating the risks by proper organisation of the scheme elements, while 
individuals also demonstrate the tendency of risk avoidance by postponing effective retirement.

It should be noted that among the risks threatening the sustainability of the system, there are also political risks. They are designed to be mitigated by properly drafted legislation, a broad discussion of planned reforms, and constitutional review of accepted amendments and regulations.

\section{PILLAR II: PRIVATELY MANAGED MANDATORY FULLY FUNDED SCHEMES}

The main rationale for the introduction of private pension systems was the intention to reduce public pension liabilities in the long run. Thus, OECD estimations for Lithuania show that an average-earner who started their career in 2016 after retirement (at the statutory retirement age) would receive more than half of their pension income from private pre-funded schemes (Maciej 2018). The capital being accumulated in funded pillars has been growing constantly, and in 2018 net equity of households in mandatory and voluntary pension fund reserves accounted for 15.3 per cent of gross domestic product in Estonia, 13.8 per cent in Latvia and 7.1 per cent in Lithuania. In 2018, the second-pillar pension plans covered practically all the working population in Latvia, 96 per cent of the working population in Estonia and 92.8 per cent in Lithuania (Better Finance 2019).

Practically, the great majority of potential voluntary participants ${ }^{6}$ in all three countries have exercised their right to join the scheme. Those who have joined the second pillar voluntarily do not have the right to opt out of the scheme, with the two temporary exclusions from this rule that occurred in Lithuania. The first time the 'door' was open was for nine months in 2013, before the introduction of a new financing model. The participants were then able to choose to either stay under the previous model, accept new rules or switch back to the fully PAYG scheme. But only 2.1 per cent of the second-pillar participants used this opportunity to withdraw from the funded scheme in 2013. Although they stopped contributing, the already accrued accumulations remained in pension funds and were not returned to the Pillar I scheme. The door opened for the second time in 2019, when a cardinal reform took place and the unit holders were again offered a choice: to accept new rules (chosen by 81 per cent of participants), take a temporarily contribution vacation (16 per cent) or quit participation in Pillar II and transfer the accumulations into individual social insurance pension schemes in Pillar I (3 per cent).

The risk of fluctuations in financial markets has been assigned to future pensioners, who therefore risk losing their savings in the event of a collapse of the markets (which happened during the global financial crisis in 2008-2009). Pension legislators in the Baltic states have not provided any protection to 
funded-pillar participants by the way of setting minimum guaranteed rates of return, unlike other Central and Eastern European (CEE) countries, where partial privatisation of public pensions took place at the turn of the 21 st century. In the rest of the region, the guaranteed minimum yield was set on the basis of industry's average (as it was in Bulgaria, Croatia, Poland and Romania), or in the form of absolute return guarantees of protection of a nominal rate of return ('at least zero' in the Czech Republic, Romania and the Slovak Republic) or a real rate of return ('at least real value of accumulated assets' in Hungary) (Kawinski, Stanko and Rutecka 2012).

That means, in fact, that pension funds do not bear any financial risks: whatever the result of the investment, even if it is negative, managers in any case will receive their fixed fee (calculated as a percentage of the net value of assets). The fee rates of Baltic pension asset managers were seen as unduly high until recently, when significant cuts were introduced in all three countries and the fees were tightly linked to the effectiveness of pension plans.

As was stressed in the recent OECD review of Latvian pension systems (OECD 2018), when the fee rate is linked to the net asset value, a manager is more interested in boosting the assets not by more efficient investments, but by increased advertising campaigns. That is, while good performance can attract new members, advertising a fund may be more powerful. All financial operations of pension funds are carried out through a custodian bank. Therefore, asset managers pay commissions to their custodian bank, while the bank in turn can advertise products for which it is a custodian to its clients.

This is definitely the case in the two other Baltic countries as well. The market of pension fund managers is quite concentrated. The market leaders in all three countries are branches of the Sweden-based Swedbank. At the end of 2018, Swedbank controlled 41.8 per cent of all Pillar II assets in Latvia (having 42.2 per cent of all participants), 37.1 per cent of assets/39.9 per cent of participants in Lithuania and 41.7 per cent of assets in Estonia (in Estonia it is possible to have units in more than one plan, which makes it impossible to calculate the share of participants). The second place is occupied by subsidiaries of another Swedish bank, SEB: 24 per cent of assets/22.9 per cent of participants in Latvia, 25.4 per cent of assets/22.5 per cent of participants in Lithuania and 18.8 per cent of assets in Estonia. So, the two market leaders in asset management together constitute more than 60 per cent of the market (Bank of Lithuania 2020; Pensionikeskus 2020; State Social Insurance Agency 2019). Asset managers barely compete on fees, as most of them charge the maximum allowed by regulation (OECD 2018, p. 121). 


\section{Risks of Funded Schemes: Accumulation Stage}

The state participates in the mandatory funded pillar as a general supervisory authority that licenses and controls market participants, virtually eliminating the risk of complete loss of pension capital or the appearance of unprofessional providers on the market. It also sets limits on the acceptable structure of investment portfolios, management fees, and so on, that are designed to protect the interests of contributors.

The main risk for individual participants is to face a low return on their pension capital, insufficient to ensure the anticipated annuity during their retirement. In highly volatile financial markets, even long-term returns are very sensitive to entry and exit dates (both of them being beyond the control of an individual). 'Unless long term net returns are significantly positive (in the upper single digits), saving early and significantly will not provide a decent replacement income through retirement' (Better Finance 2019, p. 23). The experts (ibid., p. 32) list the following net real-returns drivers:

1. asset allocation of pension products;

2. performance of capital markets into which pension products are invested;

3. skills of asset managers in terms of choosing securities and market timing;

4. fees and commissions charged by asset managers and other financial intermediaries;

5. and, ultimately, inflation and tax burdens.

An individual pension plan participant has some control (although quite limited) over only the first factor of the above list; that is, choosing a pension plan with the appropriate investment strategy. Funds participants in the Baltics may choose an investment strategy by selecting a conservative, balanced, active or aggressive pension plan, defined by the allowed share of stocks in a portfolio. Conservative plans do not allow stocks at all, so they are recommended to people in their last 10 pre-retirement years to avoid excessive fluctuations of assets' values. Recently, life-cycle plans have been introduced as well, in which a portfolio composition changes as the participant gets older, thus mitigating the risk of choosing an inappropriate plan. The seriousness of that risk is backed by the Central Bank of Lithuania's 2016 report, which states that more than 50 per cent of participants have chosen the wrong pension fund considering their age. More than two-thirds are passive investors and choose one pension fund for their whole life. In 2014-2015, for example, only 2 per cent of all participants changed their pension fund or asset management provider. Active clients follow short-term results and 92 per cent made the wrong decision during the financial crisis in 2008 (Better Finance 2019, p. 322). Similar conclusions have been reached by other researchers: most Pillar II 
participants are irrational in selecting participation rates; they make irrational choices on selecting the pension and changing it over the accumulation period. Pension fund participants are passive and tend not to change pension funds during the accumulation period, while those participants who did change funds made irrational decisions and chose inappropriate ones. So, in peak periods in stock markets, the majority of Pillar II participants in Lithuania switched from the funds with a lower proportion of equities to those with a higher proportion, or changed their pension fund to a fund in the same investment risk category. Moreover, in bottom periods in stock markets, most participants did the opposite, switching from funds with a higher proportion of equities to those with a lower proportion (Medaiskis, Gudaitis and Mečkovski 2018).

The recent (2018) reform of Pillar II in Lithuania introduced automatic enrolment of Pillar II participants into life-cycle plans according to their age. It is worth mentioning that Pillar II regulation in Lithuania allows a much riskier investment strategy: the allowed share of stocks for the most aggressive pension plans is from 50 per cent to 75 per cent in Estonia and Latvia, where these plans are not very popular: only 6.6 per cent of pension fund assets in Latvia and 18.2 per cent in Estonia were invested in such plans at the end of December 2019; meanwhile, Lithuanian life-cycle plans (for the people born in 1968 and later) that invest from 83 per cent to 98 per cent of their assets into stocks constituted 70 per cent of all Pillar II investments. Presently, there are no zero-stock pension plans in Lithuania at all. Is such a high investment risk justified?

To a marginal extent, an individual participant may have influence on the third factor, inducing 'natural selection' of the best-skilled fund managers by switching between providers. The idea that pension fund participants would actively monitor their savings and rationally switch from less successful plans to more successful ones found almost no evidence. The research showed that in fact people exercise almost no control over their pension accounts, and their decisions are driven by advertising campaigns rather than rational considerations (see Rajevska 2018). International research (Lussardi and Mitchell 2011) has also shown that people with higher levels of education, who as a rule have higher incomes, are generally better informed on financial matters and are less vulnerable to the risk of choosing an inappropriate pension savings product. Less educated people, whose incomes are lower, are more exposed to the risk of making the wrong investment choice. In this context, funded pillars are rendering a disservice to the lifetime poor, causing further distortion in income distribution in the old age.

Although an individual scheme participant has no control over the performance of capital markets, fees and commissions charged, as well as inflation and taxes, all possible negative consequences of these factors on the return on pension capital fall on the shoulders of an individual participant. 
The rates of return demonstrated so far by private pension funds in the Baltic states are very disappointing. Yearly real returns of private pension funds were one of the lowest among European countries: during the period 2003-2018, Pillar II funds in Latvia demonstrated real growth of -0.72 per cent (that is, the investments were not even intact against inflation) and Pillar II funds in Estonia during the same period returned -0.01 per cent annually, while in Lithuania the real average growth rate was better: +0.67 per cent (but the reference period is one year shorter: 2004-2018) (Better Finance 2019). The year 2019 improved the cumulative results, as all three Baltic countries faced quite high nominal yields, but the beginning of 2020 was marked by the worst crisis, followed by a gradual recovery.

Underperformance was a 'family trait' of almost privatised public pension schemes established during the pension privatisation boom at the turn of the century, accompanied by high transition costs outreaching the initial overoptimistic projections. Mandatory privately managed fully funded 'second pillars' have been established in practically all post-communist CEE countries during pension reforms in the beginning of the century. In contrast to the situation in the Baltic states, their status in other countries of the region has seriously weakened in recent years following the crisis: the Czech Republic and Hungary have abolished their mandatory pillars, Poland made participation voluntary, and Bulgaria, Slovakia and Croatia eased opting out from the scheme (Fultz and Hirose 2019). Until recently, the governments of the Baltic states did not question the need to maintain mandatory private pension funds. There was also no possibility to leave the second pillar, except for the already mentioned temporary windows in Lithuania in 2013 and 2019.

In this regard, the pioneer (once again) in the region is Estonia, where in January 2020 the parliament voted for significant changes to the pension system. It foresees, in particular, that the statutory funded scheme will be maintained, but with very significant modifications. Despite automatic enrolment of all new labour market entrants, it will be possible to opt out of the pension fund at any time. The payouts will be made within two years and the beneficiary will have to pay income tax. In addition, it will be possible to transfer payments and shift the contribution from the pension fund to an individual investment account (that is, a personal bank account that can only be used for investment purposes). The payouts from the pension fund to an investment account will be made within two years of submitting an application. It will be possible to withdraw money from an investment account at any time, paying income tax. Calculations show that staying in the statutory funded scheme would be beneficial to people who earn more than 60 per cent of the average salary, while for lower-earners it might be more advantageous to opt out and direct all social tax to the PAYG pillar. However, the adopted law was not 
proclaimed by the president, who questioned its constitutionality and sent it to the Supreme Court for consideration (Piirits and Laurimäe 2020).

Although some people in Estonia welcome the anticipated reform as 'the abolition of serfdom', many others point out that financial myopia is the main economic rationale for guaranteed lifetime pensions. When workers are left to their own devices, many would save inadequately for retirement and recognise their error only when it is too late.

The risk management strategies at the Pillar II accumulation stage are mainly risk reduction and risk retention.

\section{Risks of Funded Schemes: Payout Stage}

When the accumulation phase is over and a fund participant retires, the pension fund transfers the money to a life insurance company chosen by the participant, which in reality means that the pension fund bears no more risks or obligations. All further obligations and risks are undertaken by the life insurance company.

This exit path is expected to become the mainstream one; however, as of today, the accumulated savings are often insufficient to buy a life insurance policy, and many of those who are retiring now have to use other options. Depending on the accumulated amount, in Estonia and Lithuania it can be receipt of the entire sum at once or receipt of regular payments from the pension fund. In Lithuania, where the funded pillar was launched later and contributions to the scheme were lower than in Latvia and Estonia, fewer than 1 per cent of retired participants received life insurance annuities in 2018 (Lazutka, Poviliunas and Zalimiene 2018).

In Latvia, quite a different payout mechanism is in operation. Should the accumulated amount be lower than necessary ${ }^{7}$ for purchasing a life pension policy, ${ }^{8}$ the capital would be transferred back to the state social budget from a private pension fund and added to the notional pension account in the PAYG scheme, and then the total would be converted into an annuity by dividing the total capital by the remaining life expectancy. This can be also done if the accumulated amount is sufficient for purchasing a life pension policy from a private insurer, should a pensioner not want to buy a life pension policy from a private provider. The choice is not an easy one. As shown by OECD experts (OECD 2018, pp. 125-126), when the capital is transferred to a notional account, its rate of return is actually equal to the indexation of pensions in payment - that is, inflation plus part of the real wage growth; however, only part of the pension up to a threshold is indexed. Meanwhile, traditional life annuities of insurance companies apply the risk-free rate of return when calculating annuity payments, leading to a larger retirement income from life pension insurance than from state social insurance. At the same time, in order to protect the lifetime payments from inflation, low- and middle-earners may 
prefer the option of appending Pillar II accumulations to a Pillar I notional account rather than buying life pension insurance. Other factors, such as a possibility to specify an additional beneficiary (heritability) and behavioural inertia, may tilt in favour of one of the other options, where risk assessment is in the hands of pensioners themselves.

Although insurance companies could offer inflation-indexed policies, in practice they do not, and life pensions are not safeguarded from inflation. In Estonia, the legislation stipulates that life insurance payments shall be equal or increasing (but the growth cannot be more than 3 per cent per year). In Latvia, life pension insurers offer either equal payments throughout the whole length of the policy or split the payout period into three sub-periods. The payments within each sub-period are equal, and it is possible to have the payment amount decreasing in each subsequent sub-period. So, the great majority of Pillar II pensions will not maintain their value over time. Only one country in CEE, Croatia, requires price adjustment of second-pillar pensions in the same manner as first-pillar public pensions. This requirement provides essential protection for pensioners but is designed in a way that poses a risk for the pension provider, due to the uncertainty of future inflation rates. Governments can mitigate such risks by issuing inflation-indexed bonds. Through investing in them, private insurers can shift the risk of uncertain inflation rates to taxpayers (Fultz and Hirose 2019, p. 13).

In Lithuania, from July 2020, private life insurance companies in the payout phase have been substituted by the State Social Insurance Agency. The agency offers three types of annuities:

- standard annuities (all accumulated capital is converted into an annuity that is not heritable);

- standard annuities with a guaranteed payment period (all accumulated capital is converted into an annuity that is heritable if a person dies before the end of the guaranteed payment period; that is, before reaching the age of 80. This option provides for lower payments than the option of simple standard annuities);

- deferred annuities (a part of the accumulated capital is frozen and is converted into an annuity only upon achieving a very old age ( 85 years), and this part is not heritable; the rest of the accumulations remain in the pension fund that provides the pensioner with periodic payments from the capital, and the pension capital remaining in the fund is heritable. Periodic payments are lower than the payments in the two previous options).

It is also important to note that in Estonia and Lithuania, the beginning of receiving payments from Pillar II accumulations does not necessarily coincide with the commencement of receiving pension benefits from Pillar I. Having 
reached the retirement age, a person may obtain the status of a pensioner and start receiving a social insurance pension, but do nothing with the accumulated pension capital in Pillar II, waiting, for example, for a more favourable market price for their pension fund units and keeping on earning interest on the capital. This was also the case in Latvia - but starting from 2020, applying for the Pillar I pension automatically means the simultaneous conversion of the Pillar II pension capital into an annuity. This puts those having to retire in times of crises, when the value of pension fund units falls, in a very unfavourable position. Latvian legislators recognised the problem, and in early April 2020 a transitional provision was added to the law: those who retire during the coronavirus crisis could keep their second-pillar accumulated capital untouched until the end of November 2021, waiting for a more favourable rate.

The mix of risk management strategies includes risk sharing (purchasing a life insurance policy, use of the state social insurance PAYG pillar), risk transfer (from pension fund to an insurance company), risk mitigation and risk acceptance (in individual strategies of pensioners).

\section{PILLAR III: PRIVATELY MANAGED VOLUNTARY FULLY FUNDED SCHEMES}

At the end of 2018 Pillar III schemes ${ }^{9}$ covered $_{23}$ per cent of the economically active population in Latvia, 17 per cent in Estonia and 4.4 per cent in Lithuania (Better Finance 2019).

Although there are regulations for defined benefit plans or DC plans offering guarantees, in practice only DC plans with no guarantees are offered by private pension funds, where all the risks are borne by the members. The average annual real rates of return in Estonia and Latvia were slightly better than in Pillar II (although significantly underperforming when compared to most private pension savings providers in other European countries), and in Lithuania they were lower than in Pillar II.

In general, the risks in voluntary pension funds are almost the same as in Pillar II funds. In this regard, some important notes should be made:

- Pillar III investment strategies are far more aggressive (investing more in equities) than Pillar II funds; therefore the assets are more vulnerable to market fluctuations.

- Management fees in Pillar III funds are not capped and are significantly higher than in Pillar II; in addition, redemption fees are applied for withdrawal of the funds.

The most common forms of receiving benefits from voluntary private pension funds are a lump-sum payment or programmed withdrawals. Since acquisition 
of an annuity is not mandatory, the participants of Pillar III funds can be called participants in 'pension' accumulation with some reservations only (Pastukiene 2017, p. 9).

The mix of risk management strategies applied in Pillar III is similar to the Pillar II mix discussed above.

\section{CONCLUSION}

The pension systems of Estonia, Latvia and Lithuania were designed in the second half of the 1990s, when these countries were, to a much lesser extent, included in the global economic and financial markets. Small national states have limited ability to intervene in the market processes, and the systems were not prepared enough for the risks caused by globalisation as they were tailored for countries where people do not move abroad for work and pension funds make investments into the domestic economy.

There are more similarities than differences in the approaches to managing risks in pension systems in the Baltic states. The paradigm of mandatory privatisation of a significant share of state pensions that amplified the level of social inequality is being replaced by a new paradigm in which governments 'nudge' rather than require workers to contribute to supplemental private saving plans for retirement. At the same time, the focus on the relationship between pensions and earnings is being replaced by a focus on ensuring a decent pension standard for all. Another trend is the increase in the share of the general budget contributions in financing old-age pensions.

Development of the Baltic pension systems in the last decade shows that Estonia and, to a lesser extent, Lithuania are more in line with this paradigm shift than Latvia, with its invariably neoliberal approach to pension insurance. In the most recent years, the common features of the transformations in the Baltic pension systems include raising the retirement age, curbing management fees in Pillar II and enhancing the role of seniority. However, seniority plays a much more important role in pension formulas in Estonia and, particularly, in Lithuania than in Latvia. Estonia is reforming the early retirement scheme and links the statutory age to life expectancy. The tendency to a strong increase in vertical redistribution is present in Estonia and Lithuania, but it is achieved by different tools: Estonia changes the pension point calculation, while Lithuania has incorporated a subsistence minimum into the pension benefit. Lithuania has also considerably changed the financing of pensions and the design of the mandatory funded pillar. A fundamental reform of Pillar II is also expected in Estonia, but the essence of the planned changes is fundamentally different from the Lithuanian one.

The analysis of the existing pension schemes in the Baltic states proves that the countries use a wide range of different risk management strategies in 
designing their pension systems. Risk sharing is the major method of social insurance pension components in Pillar I, as well as in life pension insurance in the payout stage of funded pillars; risk mitigation is achieved on an individual level by maintaining individual pension accumulation accounts (notional accounts, points accounts, accumulations in the funded schemes) and on a state level by setting pension regulation and control over the performance of pension system actors. Risks are transferred between the pillars and between the actors, and a fair share of risk is transferred to parties outside the system (what is sometimes called the fourth pension pillar): other social security programs at state and municipal levels, families, charities. Certain risks are accepted as a necessary part of the system (for example, market fluctuations). Risk avoidance strategy can be traced as an individual intention to work as long as possible.

\section{ACKNOWLEDGEMENT}

The chapter has been prepared with the support from the Post-Doc Latvia Project No. 1.1.1.2/VIAA/1/16/056.

\section{NOTES}

1. The Convention is not ratified by any of the Baltic states. However, it is referenced as the basis for the European Social Security Code and serves as an instrument engaging the EU Acquis Chapter 19 (Social Policy and Employment).

2. Apart from the contributions made by the state budget for young parents as parental pensions.

3. The financial crisis that hit Russia in 1998 resulted in the Russian government and the Russian Central Bank devaluing the ruble and defaulting on debt. The crisis had severe impacts on the economies of many neighbouring countries.

4. The comparison will be made between the average life expectancy in 2018-2022 and the average life expectancy in further five-year periods. For example, to define the statutory retirement age in 2027, the average life expectancy in 2018-2022 will be compared with the average life expectancy in 2019-2023, and if the latter turns out to be higher, the statutory age will be increased by the difference (rounded to full months); in 2028, the average life expectancy in 2018-2022 will be compared to average life expectancy in 2020-2024, and so on.

5. Old-age pensions in the terms of ESSPROS (European System of Integrated Social Protection Statistics) data include not only social insurance pensions, but also social assistance pensions for those who do not have a sufficient contribution record. Social assistance pensions are financed from general taxation.

6. The second pillar is mandatory in Estonia for people born in 1983 and later, and in Latvia for people born on 1 July 1971 and later. Participation is voluntary in Lithuania irrespective of age; in Latvia it is voluntary for those born between 2 July 1951 and 30 June 1971; and in Estonia it was open for voluntary subscription until 31 October 2010 for those born in 1942-1983. 
7. In contrast to Estonia, the said amount is set in absolute numbers in euros and not as a ratio to the annually indexed national pension. Lithuania switched from a relative benchmark to absolute numbers in 2020 .

8. In Latvia, 'life pension' ('mūža pensija') is a special legal term, and it is different from life insurance ('dzìvîbas apdrošināšana'). This is a particular kind of life insurance policy that is designed specifically for Pillar II pensions and regulated separately.

9. Only pension funds' participants are counted, apart from life insurance companies' clients.

\section{BIBLIOGRAPHY}

Bank of Lithuania (2020). 'Performance indicators for pension accumulation: Results of 2nd pillar pension funds', accessed 20 March 2020 at www.lb.lt/en/pf-performance -indicators\# ex-1-1.

Better Finance (2019). 'Pension savings: The real return 2019 edition', accessed 20 March 2020 at https://betterfinance.eu.

Dorfman, M.S., and D.A. Cather (2013). Introduction to Risk Management and Insurance (10th Edition), Prentice Hall Series in Finance, Boston: Pearson.

Dunajevas, E., and D. Skučiene (2016). 'Mandatory pension system and redistribution: The comparative analysis of institutions in Baltic States', Central European Journal of Public Policy, 10(2), 16-29.

Ebbinghaus, B. (2019). 'Pension reforms and old age inequalities in Europe: From old to new social risks?', paper presented at the 14th European Sociological Association Conference, Manchester, UK, August 20-23. Accessed 20 March 2020 at www.researchgate.net/publication/335228524_Pension_reforms_and_old_age inequalities_in_Europe_From_old_to_new_social_risks.

Eurofound (2017). Extending Working Life: What Do Workers Want?, Dublin: Eurofound.

European Commission (2018). Pension Adequacy Report 2018: Current and Future Income Adequacy in Old Age in the EU, Volume II - Country Profiles, Brussels: European Commission.

Eurostat (2020). EU Statistics on income and living conditions (EU-SILC), The European System of Integrated Social Protection Statistics (ESSPROS). Accessed 20 March 2020 at https://ec.europa.eu/eurostat/data/database.

Financial and Capital Market Commission (2019). 'Valsts fondēto pensiju shēmas līdzekḷu pārvaldīšana 2018. gada 4. ceturksnī’ [State funded pension asset management in the IV quarter of 2018], accessed 20 March 2020 at www.fktk.lv/statistika/ pensiju-fondi/ceturksna-parskati/.

Fultz, E., and K. Hirose (2019). 'Second-pillar pensions in Central and Eastern Europe: Payment constraints and exit options', International Social Security Review, 72(2), 3-22.

International Labour Organization (2017). World Social Protection Report 2017-19: Universal Social Protection to Achieve the Sustainable Development Goals, Geneva: ILO.

Jankauskiene, D., and T. Medaiskis (2011). ASISP Annual National Report 2011: Pensions, Health Care and Long-Term Care - Lithuania, Brussels: European Commission. 
Jankauskiene, D., and T. Medaiskis (2012). ASISP Annual National Report 2012: Pensions, Health Care and Long-Term Care - Lithuania, Brussels: European Commission.

Kawinski, M., D. Stanko and J. Rutecka (2012). 'Protection mechanisms in the old-age pension systems of the CEE countries', Journal of Pension Economics and Finance, $11,581-605$.

Lazutka, R. (2006). 'Pension Reform in Lithuania', in E. Fultz (ed.), Pension Reform in the Baltic States, Budapest: ILO, pp. 267-350.

Lazutka, R., A. Poviliunas and L. Zalimiene (2018). On-Going Discussions about the Financing of the Statutory Funded Pension in Lithuania, ESPN Flash Report 2018/29, European Social Policy Network (ESPN), Brussels: European Commission.

Leppik, L., and A. Võrk (2006). 'Pension Reform in Estonia', in: E. Fultz (ed.), Pension Reform in the Baltic States, Budapest: ILO, pp. 17-142.

Lussardi, A., and O.S. Mitchell (2011). 'Financial literacy around the world: An overview', Journal of Pension Economics and Finance, 10, 497-508.

Maciej, L. (2018). 'Lithuanian pension system in the international perspective', presentation from the conference Lithuanian Pension System: How to Ensure Socially Just and Sustainable Pensions on 17 September 2018, accessed 20 March 2020 at www.lb.lt/uploads/documents/files/Lis_Maciej_OECD.pdf.

Medaiskis, T., T. Gudaitis and J. Mečkovski (2018). 'Second pension pillar participants' behaviour: The Lithuanian case', Entrepreneurship and Sustainability Issues, 6(2), 620-635.

OECD (2018). OECD Reviews of Pension Systems: Latvia, Paris: OECD Publishing.

Pastukiene, V. (2017). 'Lithuanian country fiche on pension projections 2018', accessed 20 March 2020 at https://ec.europa.eu/info/sites/info/files/economy-finance/final country fiche lt.pdf.

Pensionikeskus [Pension Center] (2020). 'Statistics on funded pensions', accessed 20 March 2020 at www.pensionikeskus.ee/en/statistics/.

Piirits, M., and M. Laurimäe (2020). Estonia's Statutory Funded Pension Scheme on the Way to Being Made Voluntary, ESPN Flash Report 2020/07, European Social Policy Network (ESPN), Brussels: European Commission.

Rajevska, O. (2014). 'Pension statistics in Latvia: Resources and weaknesses', Journal of Economics and Management Research, 3, 65-74.

Rajevska, O. (2018). 'The Financial Illiteracy of Latvians Undermines their Well-being in Old Age', in F. Chybalski and E. Marcinkiewicz (eds), Contemporary Problems of Intergenerational Relations and Pension Systems: A Theoretical and Empirical Perspective - Proceedings of PenCon 2018 Pensions Conference, 19-20 April 2018, Lodz, Poland, Lodz: Lodz University of Technology Press, pp. 243-251.

Rajevska, O., and I. Voroncuka (2019). 'Modelling the Influence of Working Career Breaks on Pension Using Retrospective Simulation: A Case of the Baltic States', in N. Callaos, B. Peoples, B. Sánchez and M. Savoie (eds), Proceedings of the 23rd World Multi-Conference on Systemics, Cybernetics and Informatics, July 6-9, 2019, Orlando, Orlando: International Institute of Informatics and Systemics, Volume 4, pp. 54-58.

Spasova, S., and T. Ward (2019). Financing Social Protection in Europe: A Study of National Policies 2019, European Social Policy Network (ESPN), Brussels: European Commission.

State Social Insurance Agency (2019). 'Pārskats par valsts fondēto pensiju shēmas darbību 2018. gadā' [Review of the state funded pension scheme performance in 
2018], accessed 20 March 2020 at www.vsaa.gov.lv/pakalpojumi/stradajosajiem/2 -pensiju-limenis/parskati-par-valsts-fondeto-pensiju-shemas-darbibu/.

Vanovska, I. (2006). 'Pension Reform in Latvia', in E. Fultz (ed.), Pension Reform in the Baltic States, Budapest: ILO, pp. 143-266.

Võrk, A., L. Leppik and S. Segaert (2010). ASISP Annual National Report 2010: Pensions, Health and Long-Term Care - Estonia, Brussels: European Commission. World Bank (1994). Averting the Old Age Crisis: Policies to Protect the Old and Promote Growth, Oxford: Oxford University Press. 